\title{
Knowledge Creation and Conversion in Military Organizations: How the SECl Model is Applied Within Armed Forces
}

\section{Andrzej Lis}

\begin{abstract}
The aim of the paper is to analyze the knowledge creation and conversion processes in military organizations using the SECI model as a framework. First of all, knowledge creation activities in military organizations are identified and categorized. Then, knowledge socialization, externalization, combination and internalization processes are analyzed. The paper studies methods, techniques and tools applied by NATO and the U.S. Army to support the aforementioned processes. As regards the issue of knowledge socialization, counseling, coaching, mentoring and communities of practice are discussed. Lessons Learned systems and After Action Reviews illustrate the military approaches to knowledge externalization. Producing doctrines in the process of operational standardization is presented as a solution used by the military to combine knowledge in order to codify it. Finally, knowledge internalization through training and education is explored.
\end{abstract}

Keywords: SECl model, military organizations, knowledge socialization, knowledge externalization, knowledge combination, knowledge internalization, counseling, coaching, mentoring, communities of practice, lessons learned systems, after action reviews, operational standardization, military training and education, military exercises.

\section{Introduction}

Discussing dynamic organizational capabilities in the military context, Nonaka (2012, p. 19-30) develops the concept of wise (phronetic) leadership. The concept is based on his seminal model of organizational knowledge creation ( $\mathrm{SECl}$ model) explaining the processes of knowledge socialization, externalization, combination and internalization (Nonaka, 1991; Nonaka and Takeuchi, 1995). Nonaka claims that the conversion between tacit knowledge and explicit knowledge integrates organizational creativity and efficiency. Therefore, the SECI spiral is the source of innovations in any kind of organization, including armed forces. 
The SECl framework is inseparable from the Nonaka's concept of Ba originating from the Japanese philosophy. According to the concept, knowledge is generated within relationships. Ba describes the relationship space establishing the foundation of the flow and conversion of knowledge. Nonaka and Konno (1998) identify the four types of Ba: originating, interacting, cyber and exercising. Representing the knowledge socialization phase, originating $\mathrm{Ba}$ is characterized by face-to-face relationships of individuals who "share feelings, emotions, experiences, and mental models". Interacting Ba supports the conversion of knowledge from tacit to explicit (externalization) through sharing and analyzing mental models of other people. In the case of cyber $\mathrm{Ba}$, the combination of explicit knowledge is supported by IT tools. Exercising Ba facilitates knowledge internalization through training.

Nonaka's views triggered the inspiration to ask the question: how do military organizations apply the SECl model to create knowledge and innovations? The aforementioned statement of the research problem determined the following operational objectives of the paper: (1) to identify knowledge creation activities in military organizations and to categorize them in accordance with the SECI model; (2) to identify methods, techniques and tools applied by military organizations to support the processes of knowledge socialization, externalization, combination and internalization.

The paper consists of the introduction, five sections and conclusions. The first section analyzes the approaches to knowledge management and knowledge cycle in military organizations. The subsequent sections discuss the four knowledge creation processes according to the SECI model (socialization, externalization, combination and internalization). The survey of the literature and military publications (i.e. doctrines, directives, manuals, handbooks) was the main research method applied to achieve the aim and objectives of the study. The research attention was focused on the solutions and approaches applied in NATO and the U.S. Army. Owing to the unlimited distribution of the paper, only unclassified sources were used for analysis. Moreover, the author's experience in implementing knowledge management solutions in the Polish Armed Forces as well as observations and insights shared by other military personnel contributed to the project.

\section{Knowledge management in military organizations}

The imperative of managing knowledge in an efficient and effective way is extended far beyond business organizations. Managing knowledge and information as well as organizational learning are considered as the prerequisites in military organizations. Therefore, the armed forces pay more and more attention to knowledge management issues. As observed 
by McIntyre, Gauvin and Waruszynski $(2003$, p. 38) knowledge management in military organizations is based on the same assumptions as corporate knowledge management. The difference is in the context, content and pace and that is why military organizations require: "knowledge processes that are robust and reliable within operational contexts"; "knowledge content and intellectual assets that are focused, precise and reliable, with suitable recall levels" and "knowledge creation and conversion processes that match the pace of operations". Members of military organizations often operate in highrisk and high-stake situations in dangerous environments. In combat, which is an extreme case, soldiers risk their lives fighting directly with enemies. They bear the responsibility for the accomplishment of operational aims and objectives as well as for their subordinates and colleagues. They often encounter extreme terrain and climate conditions. They are expected to operate and make the best possible decisions in highly uncertain situations. Therefore, soldiers need knowledge which is deeply embedded in the context of the operation area. They need knowledge which can be practically applied to solve the problems they encounter. They need knowledge and expertise to be available immediately when needed in order to respond properly to emerging threats and challenges. As a result, it should be highlighted that although knowledge management in military organizations derives from business, it is more akin to the approaches typical of such organizations as firefighting brigades, disaster relief teams or emergency medical service.

Both organizations under the study have developed institutionalized knowledge management solutions. According to the NATO Bi-Strategic Command Information and Knowledge Management Directive, knowledge management is defined as "a multidiscipline approach to achieving organizational objectives by making the best use of information, expertise, insights and best practices (Bi-SC 25-1, 2008, p. 1.11, as cited in Byrne and Bannister, 2013, p. 74). The U.S. Army manual on Knowledge Management Operations (FM 6-01.1, 2012, p. iv) explains the military understanding of knowledge management in a short phrase "Know, Show, Grow!". "Know" means tacit "head knowledge" of military personnel. "Show" stands for "knowledge that is written down and documented (explicit knowledge) to be shared with others". "Grow" denotes "collaboration toward innovation which sparks new knowledge". It should be emphasized that the U.S. Army "Show" goes far beyond explicit knowledge included in documents and publications. Armed forces are action-oriented organizations which highly value knowledge contributing to the achievement of aims and objectives. Therefore, all knowledge management efforts in military organizations are expected to focus on applying knowledge into practice. For instance, the Allied Joint Doctrine for the Conduct of Operations (AJP-3B, 2011, p. 4-19) 
highlights that lessons learned should contribute to the improvement of the way of doing and performance of the armed forces. "Showing value of the Lessons Learned capability to the force" is enumerated among the key success factors in U.S. military Lessons Learned programs (Lis 2012b, p. 2728). What is also important, actions and decisions are driven both by tacit and explicit knowledge of a doer or a decision maker applied in a particular context.

Recognizing the value of the practical aspect of knowledge, both organizations under the study strive for becoming learning organizations. The NATO Bi-Strategic Information and Knowledge Vision declares that "the NATO Military Structure will transform into a Knowledge Centric Organization (KCO) that deliberately and systematically exploits NATO information and expertise, and proactively manages its information and KM processes. The NATO strategic commands will promote an organizational culture that fosters information and knowledge sharing and treat information, expertise, experience, and Best Practice as valuable assets, as a fundamental capability required to achieve decision superiority" (Bi-SC IKM Vision and Strategic Concept 2007, as cited in Hutson, 2011, p. 48-49). Similarly, as officially declared in the U.S. Army manual on Knowledge Management Operations (FM 6-01.1., 2012, p. 1.13), knowledge management is to facilitate "the transformations of Armed forces into knowledge-based organizations [which] integrate best practices, the most effective and efficient method of achieving any objective or task, into operation or training". The vision of the army as a learning organization attracts the attentions of researchers who discuss and reexamine it (cf. Wheatley, 1994; DiBella, 2010). What is more, both organizations under the study are famous for their learning concepts and tools such as Lessons Learned and After Action Review, which will be discussed in details in further sections of the paper.

Both organizations under the study highly appreciate organizational learning and they strengthen close links between managing knowledge and their key activities. The knowledge management cycle which can be observed in military organizations (Figure 1) highlights the role of organizational learning and the use of knowledge to achieve organizational aims and objectives in operations and exercises. Military organizations codify their knowledge in doctrines, manuals, instructions and other publications. The explicit knowledge embedded in these documents is transferred to the troops through training and education. In the peacetime, training is considered as one of the core business activities of any armed forces, besides the participation in operations formerly defined as "military operations other than war" (MOOTW) such as peace operations, combating terrorism, humanitarian assistance, arms control etc. (cf. JP 3-07, 1995). Knowledge, skills 
and competencies acquired by military personnel in the processes of training and education are verified in military operations and exercises. Nowadays, the scope of military engagements encompasses the variety of operations such as: stability operations, civil support, foreign humanitarian assistance, recovery, non-combatant evacuation, peace operations, combating weapons of mass destruction, CBRN (chemical, biological, radiological and nuclear) consequence management, foreign internal defense, counterdrug operations, combating terrorism, counterinsurgency and homeland defense (JP 3-0, 2011, p. I-15). It should be highlighted that in all types of operations, regardless of their character, affective drivers to learn are much stronger than in training. Therefore, operations are the contexts of paramount importance for military knowledge management and learning. Identifying and learning lessons from operations and exercises update the knowledge base of military organizations. Reviewed knowledge triggers the development of new concepts. Simultaneously, military publications are updated in order to keep pace with changes in the armed forces and the environment. In effect, the knowledge management cycle is closed.

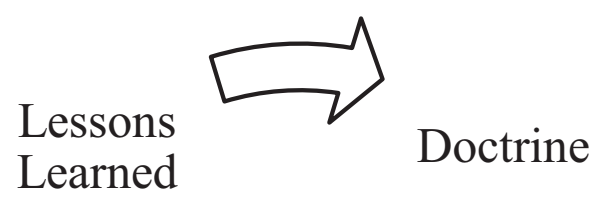

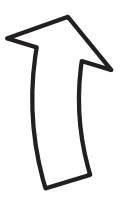

Operations and Exercises

\section{Doctrine}

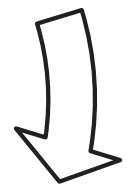

\section{Training} and

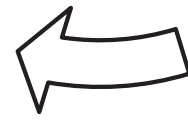
Education

Figure 1. Knowledge management cycle in military organizations

Sometimes, when military organizations operate in highly turbulent environments, lessons learned are directly translated into changes in training programs or even in the way of conduct of operations. Special forces are the branch of the armed forces famous for learning and innovations regarding tactics and weaponry which shortcut a typical "lessons learned to doctrine 
to practice" loop. Special forces are often the leaders in the implementation of effective learning and knowledge sharing initiatives in their armies. The paramount importance of sharing tacit knowledge for tactical innovations is also recognized by other armed forces which support communities of practice and professional forums such as CompanyCommand in the U.S. Army or the U.S. Air Force Knowledge Now platform.

When studied thoroughly, the aforementioned elements of the knowledge management cycle in military organizations can be categorized in accordance with the SECl model. Military organizations have developed techniques and tools corresponding to the four knowledge creation activities represented in the model (Figure 2 ).

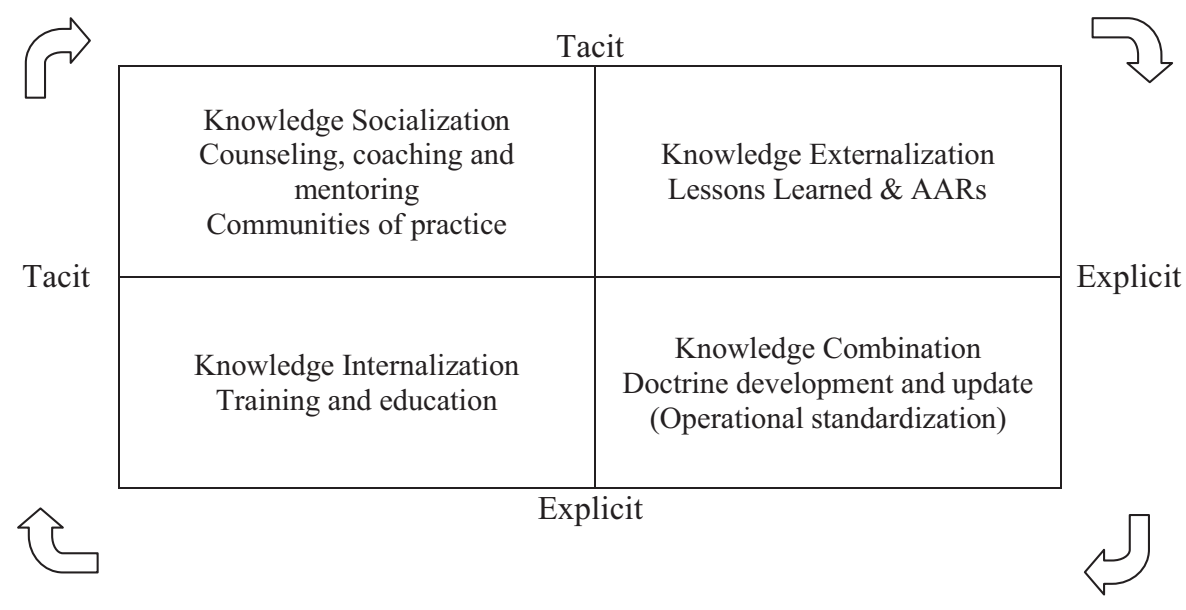

Figure 2. The examples of $\mathrm{SECl}$ processes in military organizations Source: Own study based on the SECI model by Nonaka (2012, p. 21).

In subsequent sections the four $\mathrm{SECl}$ processes identified in military organizations will be discussed. Counseling, coaching, mentoring and communities of practice will be studied from the perspective of their potential for supporting knowledge socialization. The analysis of Lessons Learned systems and After Action Reviews will illustrate the military approaches to knowledge externalization. Producing doctrines in the process of operational standardization will be presented as a solution used by the military to combine knowledge in order to codify it. Finally, knowledge internalization through training and education will be explored. 


\section{Knowledge socialization through counseling, coaching, mentoring and communities of practice}

Socialization is the process of conversion from tacit knowledge to tacit knowledge which occurs through social interactions such as apprenticeship and mentoring. Socialization is facilitated by teamwork, sharing experiences, informal communication and open workplace without barriers (Byrne and Bannister, 2013, p. 76). In order to foster knowledge socialization among their members military organizations promote the practices of counselling, coaching and mentoring. The military highly values the community (of practice and interest) concepts. Moreover, some features of socialization processes are embedded into the procedure of After Action Review which will be studied later in the section relating to knowledge externalisation.

According to the US doctrine on Army leadership (ADP 6-22, 2012, p. 8 ) counseling, coaching, and mentoring are considered as some of the tools used by a leader to provide feedback and develop other members of military personnel. As such tools they might be used to transfer tacit knowledge of a counselor, a coach or a mentor to a less experienced member of military personnel. Having the same aim, all the three aforementioned techniques differ from each other as regards to their detailed purposes, time perspective, the feedback provider or the type of interaction between participants.

Counseling is defined as "a standardized tool used to provide feedback to a subordinate" (AR 600-100, 2007, p. 5) or "the process used by leaders to guide subordinates to improve performance and develop their potential" (ADRP $6-22,2012$, p. 7.10; cf. FM 6-22, 2006, p. 8.12). Counseling is focused on the past performance and ways to improve it in the future. Within the counseling process, the interaction occurs between a leader and their subordinate. While counseling, leaders support their subordinates in identifying strengths and weaknesses, developing and implementing improvement plans, and assessing their outcomes. Subordinates are expected to be active members of the counseling process and seekers of constructive feedback. The US Army Field Manual on Army Leadership (FM 6-22, 2006, p. 8.12) identifies three types of counseling: event counseling, performance counseling and professional growth counseling.

As stated in the US Army Doctrine Reference Publication (ADRP 6-22, 2012 , p. 7.10) "coaching refers to the function of helping someone through a set of tasks or with general qualities". It is a role of a coach to support a person being coached in understanding their current level of performance and developing their knowledge, skills or competencies. Coaching is focused on the present time perspective. According to the US military regulations, in their work coaches should apply the following guidelines: focusing goals, clarifying the leader's self-awareness, uncovering potential, eliminating 
developmental barriers, developing action plans and commitment, followingup through an interaction and feedback from a person being coached (FM 6-22, 2006, p. 8.13-8.14; cf. ADRP 6-22, 2012, p. 7.10-7.11).

Mentorship is defined as "the voluntary developmental relationship that exists between a person of greater experience and a person of lesser experience that is characterized by mutual trust and respect. The focus of mentorship is voluntary mentoring that extends beyond the scope of chain of command relationships and occurs when a mentor provides the mentee advice and counsel over a period of time" (AR 600-100, 2007, p. 6). Contrary to counseling and traditional belief, the mentorship interaction is not limited to a superior-subordinate relationship and it may occur among the soldiers of different ranks. In initiating the mentorship relation the need of pro-active attitude of a less experienced soldier is highlighted. According to the Army Mentorship Handbook (2005, p. 14-15), there are five key success factors of effective mentoring relationships: respect, trust, building partnership, realistic expectations and self-perception and time necessary to develop relationships.

As regards the time perspective, mentoring is oriented to the future and to the development of the mentee potential. Therefore, the role of a mentor changes over the time to meet the changing needs of the mentee's learning and growth. The mentorship program starts from the prescriptive stage, when a novice in the army needs a coach, a motivator and a teacher. Then, in the persuasive stage the roles of a counselor and a guide become the priorities to support the mentee to answer questions and face challenges. In the collaborative stage a mentor and a mentee work together to solve problems. a mentor is to take on the responsibilities of a career advisor and a role model. Finally, in the confirmative stage, an experienced mentee is supported by a mentor with their wisdom or professional expertise and insight (Army Mentorship Handbook, 2005, p. 21-23).

As already mentioned, military organizations are action-oriented and they highly value "hot", practical knowledge learned from the field which is situation-dependent and context sensitive. Such knowledge is particularly important in operations where soldiers' lives are at the stake. Operating in risky, uncertain and stressful situations where "no doctrinal or clear-cut answers" are applicable, as highlighted by Dixon (2007, p. 14) "conversation with those facing similar issues is an essential means of deepening one's own thinking about important subjects". Therefore, soldiers need mechanisms to communicate, to share their problems and worries and to learn from each other quickly and effectively. Communities of practice are the example of such a solution used by both commanders and the rank and file. "Communities of practice are groups of people who share a concern, a set of problems, 
or a passion about a topic, and who deepen their knowledge and expertise in this area by interacting on an ongoing basis" (Wenger, McDermott and Snyder, 2002; quoted after: Jashapara, 2004, p. 203). CompanyCommand (CC), the U.S. Army community of practice integrating captains in charge of a company (a unit of about 150 troops) command, may be an interesting example illustrating this approach to knowledge socialization in military organizations. The community was established in the 1990s as a voluntary initiative of young U.S. officers in order to learn from each other. In 2000, the forum launched its website to connect their members and facilitate communication. The role of the CompanyCommand professional forum was officially recognized by the Army which provided organizational support for the community. The idea of the organization is very accurately explained by Dixon, Allen, Burgess, Kilner and Schweitzer $(2005$, p. 1) in their seminal study of the CompanyCommand case: "The cutting-edge knowledge of the Army resides in the minds of leaders at the tip of the spear. Connecting these leaders in conversation brings together the Army's greatest knowledge resources, unleashing the power of the Army profession to improve combat effectiveness".

When studied from the perspective of the internal knowledge market effectiveness (cf. Davenport and Prusak, 1998, p. 28-30), all the techniques discussed above facilitate knowledge transactions between knowledge sellers (experienced members of military personnel) and knowledge buyers (who need to be counseled, coached, provided with mentor's advice or updated with the edge-cutting knowledge from the field). The need to seek advice and counsel in order to benefit from the experience of others is highlighted by the founders of the CompanyCommand professional forum, in their book on military leadership (Allen and Burges, 2001, p. 3-4). Counseling, coaching and mentoring are the examples of institutionalized procedures fostering organization members to transfer knowledge through socialization and mechanisms established in order to improve the effectiveness of knowledge markets in military organizations. Communities of practice connect soldiers and give them the chance to exchange their lessons, opinions and insights. Simultaneously, all the aforementioned solutions enable military organizations to preserve knowledge and experience of their members (organizational memory). It is very important due to the fluctuation of personnel resulting from position rotations and frequent deployments to various areas of operation. 
Knowledge externalization through Lessons Learned (LL) and After Action Reviews (AAR)

Externalization is the process of knowledge conversion from tacit to explicit. Through externalization observation and best practices captured by a serviceperson are shared with other members of military organizations. Byrne and Bannister (2013, p. 77) enumerate the following externalization techniques: writing notes, brainstorming, encouraging a learning environment. In military organizations, Lessons Learned systems and After Action Reviews are the most common tools used to externalize the knowledge of their members.

According to the Allied Joint Doctrine (AJP-01(D), 2010, p. 5.2.) Lessons Learned and the review of doctrines are enumerated as the last stage of a NATO joint operation. It means that knowledge acquired by the troops during the operation is required to be externalized, to be transferred from tacit knowledge of operation participants to explicit knowledge available to all military personnel in doctrines, directives, manuals and other publications. Lessons Learned make a kind of a bridge between tacit knowledge experienced and acquired by the personnel and explicit knowledge embedded in military doctrines. As stated in the NATO Allied Joint Doctrine Publication for the Conduct of Operations (AJP3(B), 2011, p. 4.19) "the purpose of a Lessons Learned is to learn efficiently from experience and to provide validated justifications for amending the existing way of doing things, in order to improve performance, both during the course of an operation and for subsequent operations".

Military organizations have always valued lessons learned from wars, operations and battles and they used such lessons to change their strategies and tactics, to improve organizational structures and to modernize armaments. Mains and Ariely (2011, p. 165-176) discuss interesting examples of lessons learned and applied by the U.S. Armed Forces from World War II to Iraqi and Afghanistan operations and by the Israeli Defense Forces during the Second Lebanon War. Recognizing the increasing role of organizational learning, starting from the 1970s and the 1980s military organizations have institutionalized their lessons learned practices. The armed forces established structures responsible for lessons learned e.g. the U.S. Center for Army Lessons Learned (see more Lackey, 2003, p. 79-87) or the Joint Analysis and Lessons Learned Centre, which is the leading agent for organizational learning in NATO. Procedures for identifying and learning lessons as well as toolboxes supporting these processes have been developed (cf. Jabłoński and Lis, 2012, p. 170-182). According to the NATO model of the lessons learned system, the three aforementioned elements (i.e. structures, process and tools) create the pillars of the "Lessons Learned house". Nevertheless, in order to be 
efficient and effective, the Lessons Learned capability should be established on the foundation of positive mindset and engagement of all military personnel and the positive leadership of military commanders. Knowledge and information sharing makes the capstone of the "Lessons Learned house" (The NATO LL Handbook, 2011, p. 9). As proved by the author's research (cf. Lis, 2012a, p. 82-93; Lis, 2012b, p. 21-34) positive organizational behaviors and related issues such as organizational culture, organizational climate and leadership are the key success factors for learning lessons by military organizations. Applying the systems approach, military organizations build up and strengthen their Lessons Learned capabilities through the development of DOTMLPF-I capability components i.e. doctrine, organization, training, material, leadership, personnel, facilities and interoperability (cf. Hallet, Mota, Pinot, Smack and Soegaard, 2009, p. 41-44).

When studied thoroughly, the scope of the Lessons Learned procedure goes beyond knowledge management combining organizational learning with change management. The procedure of Lessons Learned includes identifying lessons, assigning action and implementing the change (Milton, 2010, p. 1620). This generic procedure is followed by the models of Lessons Learned processes used in military organizations. For instance, the NATO Lessons Learned process consists of six steps including observation identification, analysis, endorsement, implementation and validation of remedial actions, and the dissemination of observations and lessons learned (The NATO LL Handbook, 2011, p. 11).

The After Action Review is considered to be one of the most effective techniques supporting organizational learning and lessons learned programs. The After Action Review procedure originated in the U.S. Army in the 1970s and significantly contributed to the post-Vietnam War transformation of the U.S. military. As observed in the U.S. Army Lesson Learned handbook "[within] the U.S. Army, no concept is given more credit for changing the way it trains or fights than the AAR process. AARs help provide soldiers and units feedback on mission and task performances in training and in combat. They identify how to correct deficiencies, sustain strengths, and focus on the performance of specific mission-essential task list training objectives" (Establishing a LL Program, 2011, p. 63).

After Action Review is "a verbal, professional discussion of a unit's actions that typically occurs immediately after a training event, combat operation, or other mission that determines what should have happened, what actually happened, what worked, what did not work and why, and the key procedures a unit wants to sustain or improve" (Establishing a LL Program, 2011, p. 63). In this paper the AAR procedure is categorized as a tool for knowledge externalization. Nevertheless, it should be made clear that After Action 
Review combines various knowledge creation and conversion processes. First and foremost, it enables the military to externalize their knowledge. The whole After Action Review process, and its modifications such as Before Action Review (BAR) and During Action Review (DAR), are built on the value and methodology of Lessons Learned. The potential of the procedure to convert tacit knowledge into explicit knowledge is even more visible when externalized knowledge is codified as an After Action Report - "a written report that is typically submitted after a training, combat operation, or other mission that normally documents a unit's actions for historical purposes but also provides key observations and LL" (Establishing a LL Program, 2011 , p. 63). Nevertheless, both socialization and internalization processes are embedded into After Action Reviews, too. Conducting an analysis of what happened, what was effective and what still needs an improvement, soldiers share their tacit knowledge (socialization). Simultaneously, through discussion and analysis the military theory in the context of real life lessons from the battle or training, military personnel increase their understanding of explicit knowledge included in military doctrines, directives and manuals (internalization).

The After Action Review procedure was imported to the business environment in late 1980s by Shell Oil at the suggestion of a retired general Gordon Sullivan, then a member of the company's board (Darling, Perry and Moore, 2005, p. 86). Nowadays, the AAR is widely recognised as an effective tool of organizational learning. Discussing the building blocks of the learning organization, Garvin, Edmondson and Gino (2008, p. 112) point out the U.S. Army After Action Review as an example of the best known example of concrete learning processes and practices. Davenport and Prusak (1998, p. 8-9) highlight the After Action Review's contribution to "ground truth" considered to be a component of knowledge. "Ground truth", which is a term borrowed from the U.S. Center for Army Lessons Learned (CALL), means "knowing what really works and what doesn't" or "the rich truths of real situations experienced close up: on the ground, rather than from the heights of theory or generalization" (Davenport and Prusak, 1998, p. 8). What is more, as highlighted by one of the experts reviewing the paper "CALL went beyond capturing Lessons Learned to exploring patterns across Lessons Learned, that is, higher-order patterns that provided insights beyond the context and situation from which they were learned". Consequently, the state of knowledge is shifted from "knowing what really works and what doesn't" to "knowing when it works and when it doesn't". Such a change results from analyzing the observations captured by soldiers in the field and building the army knowledge base through organizational learning processes. 
Summing up, it can be observed that military Lessons Learned systems are traditionally perceived as formal approaches oriented at collecting lessons in databases. Nevertheless, the reality is far more complex. Certainly, Lessons Learned databases are still in use but the armed forces are more and more oriented to sharing lessons through Internet portals and connecting their personnel through formal networks. The extending popularity of After Action Reviews is another landmark of knowledge externalization processes in military organizations. The AAR procedure offers an organized and methodological approach to solving real life problems faced by military organizations and their members. It can be applied both in a formal or informal way. The aforementioned advantages increase the AAR's potential as a technique of knowledge processing.

\section{Knowledge combination through operational standardization}

Combination means the transfer from explicit to explicit knowledge through categorizing, storing, sorting and updating knowledge, information and data (Byrne and Bannister, 2013, p. 77). In the military context, knowledge externalized through Lessons Learned processes is combined with other pieces of information, knowledge and expertise in order to produce military doctrines, manuals and other publications which standardize the way of conducting operations and doing business by military organizations.

NATO standardization is defined as "the development and implementation of concepts, doctrines, procedures and designs in order to achieve and maintain the compatibility, interchangeability or commonality which are necessary to attain the required level of interoperability, or to optimize the use of resources, in the fields of operations, material and administration" (AAP42(B), 2011, p. 22). Operational standardization relates to military practices and it is applicable to "doctrines, tactics, techniques, procedures, training, reporting, maps and charts". Material standardization covers "consultation, command and control (C3) systems, weapon systems and subsystems, interfaces, assemblies, components, spare parts and consumables, including ammunition, fuel, and supplies". Administrative standardization deals with "terminology, finances, human resources and military ranks" (AAP-3(J), 2011, p. 12).

NATO standardization process is "the sequence of activities consisting of the identification and validation of the standardization requirements as well as the achievement of the related standardization tasks, resulting in the production of the NATO standardization documents, followed by their ratification or approval, their implementation or adoption and their maintenance throughout their life cycle or their disposal" (AAP-42(B), 2011, 
p. 23). Generally, there are two ways to initiate the NATO standardization process: the top-down approach triggered by the NATO defense planning process and the bottom-up approach resulting from the need identified through the externalization of knowledge, i.e. by Lessons Learned procedures. When submitted, a standard proposal is validated. Then, a standardization task is realized through one of the following options: selecting and updating existing NATO standardization documents, developing a new NATO standard, selecting an appropriate non-NATO standard or developing/revising a dualuse standard in cooperation with civilian standardization organizations. When drafted, a NATO standard undergoes the procedures of ratification and approval by NATO member countries. While the endorsement process is completed, standardization documents are promulgated and distributed. The implementation process starts the life cycle of documents which are reviewed and updated when necessary (AAP-3(J), 2011, p. 21-47).

Knowledge acquired by military organizations and their members is combined into doctrines and other publications. Therefore, from the perspective of managing a knowledge cycle and creating knowledge, doctrine development is an important area of interest of this study. As highlighted in the preface to the NATO publication on allied joint doctrine development (AAP-47, 2013, p. III), "the planning, execution and support of military operations require clearly understood and widely accepted doctrine. This is especially important when operations are conducted by Allied and coalition forces. So, as NATO continues to transform its capabilities to meet the security challenges of the evolving environment, it is necessary for the Alliance to adapt its doctrine accordingly". The NATO Glossary of Terms and Definitions (AAP6,2013 , p. 2-D-9) defines doctrine as "fundamental principles by which the military forces guide their actions in support of objectives. It is authoritative but requires judgment in application". NATO doctrines focus their attention on procedural knowledge, explaining how to conduct operations by "capturing and promulgating commonly agreed principles that guide the employment of NATO military forces in a coordinated action towards a common objective" (AAP-47, 2013, p. 1.2.). Joint doctrines establish "a link between the 'ends' (what must be accomplished and the 'means' (capabilities) by providing the 'ways' (how) for joint forces to accomplish military strategic and operational objectives in support of NATO's goals" (AAP-47, 2013, p. 1.3).

The strategy of knowledge codification through doctrines, manuals and other publications is widespread in military organizations. Such an approach enables military organizations to provide clear guidelines for all the members from rank-and-file soldiers up to general officers. The codification of knowledge and procedures supports coordination between units, the components of armed forces (e.g. land forces, air forces, navy, special forces 
or marines) and the national contingents of coalition or alliance member countries. Nevertheless, in highly turbulent environments, it is a real challenge for military organizations to keep their doctrines updated. For instance, during military operations when tactical innovations must be captured and disseminated very quickly, lessons learned are translated directly into changes in training programs or even in the way of conduct. In such situations, a gap in the knowledge management cycle emerges. Therefore, when the situation is stabilized, military organizations make efforts to fill the gap. Therefore, the process of doctrine development through knowledge combination cannot be a one-time activity but it should be rather a long-term effort focused on continuous learning and incorporating new lessons into documents.

\section{Knowledge internalization through training and education}

Internalization is the process of creating new tacit knowledge from explicit knowledge. Learning and understanding explicit knowledge is related to practicing and repetition, experience and expertise and creating know-how (Byrne and Bannister, 2013, p. 77). In military organizations, education and training are considered as the key solutions supporting the internalization of explicit knowledge by their members. Military organizations highly value the role of training, perceiving it as the foundation for an efficient and effective conduct of operations.

The NATO education and training activities encompass four following areas: education, individual training, collective training and exercises. Education is defined as "the systematic instruction of individuals in subjects that will enhance their knowledge and skills, and develop competencies". Individual training includes "all instructional activities that provide the knowledge, skills and competencies required in the performance of assigned duties". Education and individual training make the foundation of military training. When the individual training is completed the attention is focused on collective training oriented to "procedural drills and the practical application of doctrine, plans and procedures to acquire and maintain tactical, operational and strategic capabilities". Then, the capabilities of headquarters and military units are trained and tested in military exercises which are the fourth element of the education and training system (Bi-SC 75-2, 2013, p. 9; cf. Bi-SC 75-3, 2013, p. 1.3; Bi-SC 75-7, 2013, p. 1.2). The aim of military exercises is to "ensure that $\mathrm{HQ}$ and formations are efficiently and effectively trained to fulfill their missions within the given readiness criteria" (Bi-SC 753, 2013, p. 1.3).

Taking into account the increase in the depth of knowledge, military education and training are delivered through the following forms and activities: 
elearning, residential training and courses, key leader training, training events and exercises (Bi-SC 75-2, 2013, p. 37). Military organizations recognize the growing potential of electronic learning (elearning). In December 2011, NATO issued an official e-learning concept. Due to technological changes and lessons learned from practice, the document has been reviewed and updated. Nowadays, the 4th edition is in force. According to the e-learning concept (2014, p. 7-10), NATO applies and develops the following e-learning technologies and solutions: advanced distributed learning (ADL), computerbased training (CBT), immersive learning, mobile learning (m-learning), transmedia (collaborative) learning and blended learning combining the strengths of e-learning and traditional residential education and training (cf. BiSC 75-2, 2013, p. 38; Bi-SC 75-7, 2013, p. 3.3-3.4, J4-J9). Residential courses offer a traditional way of education and individual training. Combining lectures with practical classes they cover both theoretical and practical aspects. The role of key leader training is to develop and enhance the key military leaders in their preparation for deployment to operations. Training events include battle staff training (BST), pre-deployment training (PDT) and train-the-trainers courses (T3C). The aim of battle staff training is to improve the headquarters' capabilities in mission-essential tasks integrating several functional areas. Pre-deployment training is focused on preparing individuals and units to the specific tasks and missions during the pre-planned operations. The following forms of pre-deployment training are recognized: individual PDT, key leader training (KLT) and mission rehearsal exercise (MRE). NATO military exercises can be conducted at four levels: strategic, operational/joint command, tactical/component and tactical/unit. The exercises may be of the following form: command post exercises (CPX) aimed at the training of HQs, live exercises (LIVEX) used to train forces in the conduct of operations or exercise study (map exercise, war games, discussion groups, seminars, operational analyses). Due to the advancement in information technology, military exercises may be conducted as computer-assisted exercises (CAX) applying modeling and simulation (Bi-SC 75-2, 2013, p. 38-41).

As the case of NATO shows, military organizations highly value training, education and exercises, which are perceived as key military activities during the peacetime and the prerequisites to prepare troops to conduct military operations in an efficient and effective manner. From the perspective of knowledge conversion processes, training and education activities enable military personnel to internalize knowledge, to change explicit statements included into military doctrines and manuals (knowing what) into tacit knowledge (knowing how). Moreover, collective training and military exercises stimulate learning processes at the team and organizational levels and they enable troops to test and validate their knowledge, skills and competencies. 


\section{Conclusion}

The paper contributes to the knowledge management special issue of the Journal of Entrepreneurship, Management and Innovation through exploring the relationships between the theory of knowledge conversion and the learning practices applied in military organizations. Although the $\mathrm{SECl}$ framework and its assumptions are criticized by some researchers (e.g. Gourlay, 2003; Gourlay, 2006; Powell, 2007), the model is considered to be one of the more pervasive approaches in the field of knowledge management. The findings from the analysis prove that the SECl model is applicable to managing knowledge creation in military organizations under the study. NATO and the U.S. Army have developed and applied a bunch of techniques and tools to convert their knowledge resources:

- from tacit knowledge to tacit knowledge (socialization) e.g. counseling, coaching and mentoring, communities of practice;

- from tacit knowledge to explicit knowledge (externalization) e.g. Lessons Learned systems and After Action Reviews;

- from explicit knowledge to explicit knowledge (combination) e.g. the processes of operational standardization and doctrine development;

- from explicit knowledge to tacit knowledge (internalization) e.g. the variety of training and education forms including individual training and education, collective training and military exercises.

The combination of the aforementioned techniques and tools enables military organizations to benefit from both the knowledge personalization strategy and the knowledge codification strategy. Military organizations need both of them. On the one hand, knowledge personalization based on socialization processes and sharing tacit knowledge is particularly important for "fielded warfighters" who need tactical innovations and "hot" knowledge which is context-sensitive and situation dependent. On the other hand, the military needs lessons from the field to be identified and learned by a wider community of users (externalization) as well as rules and governing principles to be codified in military doctrines and manuals (combination) and then acquired by the troops through training (internalization).

The identified toolbox of methods, techniques and procedures used to socialize, externalize, combine and internalize knowledge confirms that the military organizations under the study apply a comprehensive approach to managing what they and their members know. Nevertheless, the findings resulted from the analysis of official documents should be verified empirically in practice, which is a field for further exploration. Such a study is to be oriented to the identification of gaps between normative assumptions and the reality of knowledge management in military organizations as well as 
lessons learned and best practices which could be transferred to other types of organizations.

\section{Acknowledgements}

I would like to thank the editor, Professor Patrick Lambe and two anonymous reviewers for their insightful comments and valuable recommendations for the improvement of the paper draft.

\section{References}

AAP-3(J) (2011). Production, Maintenance and Management of NATO Standardization Documents. Brussels: NATO Standardization Agency. Retrieved from http://nsa.nato.int/nsa/zPublic/ap/aap03\%28j\%29\%282\%29e.pdf (28 Feb. 2014).

AAP-6 (2013). The NATO Glossary of Terms and Definitions. Brussels: NATO Standardization Agency. Retrieved from http://nsa.nato.int/nsa/zPublic/ ap/aap6/aap-6.pdf (28 Feb. 2014).

AAP-42(B) (2011). NATO Glossary of Standardization Terms and Definitions.

Brussels: NATO Standardization Agency. Retrieved from http://nsa.nato. int/nsa/zPublic/stanags/7186eed01.pdf (28 Feb. 2014).

AAP-47(A) (2013). Allied Joint Doctrine Development. Supplement to AAP3(J). Brussels: NATO Standardization Agency. Retrieved from http://nsa. nato.int/nsa/zPublic/ap/AAP-47\%20EDA\%20V2.pdf (28 Feb. 2014).

ADP 6-22 (2012). Army Leadership. Washington: Headquarters Department of the Army. Retrieved from http://armypubs.army.mil/doctrine/DR_ pubs/dr_a/pdf/adp6_22_new.pdf (29 Mar. 2014).

ADRP 6-22 (2012). Army Leadership. Washington: Headquarters Department of the Army. Retrieved from http://armypubs.army.mil/doctrine/DR pubs/dr_a/pdf/adrp6_22_new.pdf (29 Mar. 2014).

AJP-01(D) (2010). Allied Joint Doctrine. Brussels: NATO Standardization Agency. Retrieved from http://nsa.nato.int/nsa/zPublic/ap/ajp-01(d). pdf (28 Feb. 2014).

AJP-3(B) (2011). Allied Joint Doctrine for the Conduct of Operations. Brussels: NATO Standardization Agency. Retrieved from http://nsa.nato.int/nsa/ zPublic/ap/ajp-3(b).pdf (28 Feb. 2014).

Allen, N., Burgess, T. (2001). Taking the Guidon: Exceptional Leadership at the Company Level. Delaware: The Center for Company-Level Leadership.

AR 25-1 (2008). Army Knowledge Management and Information Technology. Washington: Headquarters Department of the Army. Retrieved from https://www.fas.org/irp/doddir/army/ar25-1.pdf (25 Mar 2014).

AR 600-100 (2007). Army Leadership. Washington: Headquarters Department of the Army. Retrieved from http://www.apd.army.mil/pdffiles/ r600_100.pdf (28 Feb 2014). 
Army Mentorship Handbook (2005). Rosslyn: Headquarters Department of the Army. Retrieved from http://www.armycounselingonline.com/ download/Mentorship\%20Handbook.pdf (14 Mar. 2014).

Bi-SC 25-1 (2008). Information and Knowledge Management Directive. Allied Command Operations \& Allied Command Transformation.

Bi-SC 75-2 (2013). Education and Training Directive (E\&TD). Allied Command Operations \& Allied Command Transformation. Retrieved from http:// www.act.nato.int/images/stories/structure/jft/075-002_BI-SC_1113.pdf (28 Feb. 2014).

Bi-SC 75-3 (2013). Collective Training and Exercise Directive (CT\&ED). Allied Command Operations \& Allied Command Transformation. Retrieved from http://www.act.nato.int/images/stories/structure/jft/bi-sc-75-3_ final.pdf (28 Feb. 2014).

Bi-SC 75-7 (2013). Education and Individual Training Directive (E\&ITD). Allied Command Operations \& Allied Command Transformation. Retrieved from http://www.act.nato.int/images/stories/structure/jft/bi-sc-75-7a. pdf (28 Feb. 2014).

Bi-SC IKM Vision and Strategic Concept (2007). Allied Command Operations \& Allied Command Transformation.

Byrne, B., Bannister, F. (2013). Knowledge Management in Defence. Defence Forces Review 2013, 71-91. Retrieved from http://www.military.ie/ fileadmin/user_upload/images/Info_Centre/documents/Annual_ Reviews/DF_Review_2013.pdf (25 Mar. 2014).

Darling, M., Perry, Ch., Moore, J. (2005). Learning in the Thick of It. Harvard Business Review, July-August, 84-92.

Davenport, T.H., Prusak, L. (1998). Working Knowledge: How Organizations Manage What They Know. Boston: Harvard Business School Press.

DiBella, A.J. (2010). Can the Army Become a Learning Organization. Joint Force Quarterly, 2010, 56, 117-122. Retrieved from http://www.dtic.mil/ dtic/tr/fulltext/u2/a515164.pdf (28 Feb. 2014).

Dixon, N.M. (2007). Company Command: a Professional Community That Works. ASK Magazine, Summer, 13-17.

Dixon, N., Allen, N., Burgess, T., Kilner, P., Schweitzer, S. (2005). Company Command: Unleashing the Power of the Army Profession. West Point: The Center for the Advancement of Leader Development and Organizational Learning.

Establishing a Lessons Learned Program: Observations, Insights and Lessons (2011). Fort Leavenworth: Center for Army Lessons Learned. Retrieved from http://usacac.army.mil/cac2/call/docs/11-33/11-33.pdf (28 Feb. 2014).

FM 6-01.1 (2012). Knowledge Management Operations. Washington: Headquarters Department of the Army. Retrieved from http://armypubs. army.mil/doctrine/DR_pubs/dr_a/pdf/fm6_01x1.pdf (25 Mar. 2014).

FM 6-22 (2006). Army Leadership: Competent, Confident and Agile. Washington: Headquarters Department of the Army. Retrieved from 
http://armypubs.army.mil/doctrine/DR_pubs/dr_a/pdf/fm6_22.pdf (25 Mar. 2014).

Garvin, D.A., Edmondson, A.C., Gino, F. (2008). Is Yours a Learning Organization? Harvard Business Review, March, 109-116.

Gourlay, S. (2003). The SECI Model of Knowledge Creation: Some Empirical Shortcomings, 4th European Conference on Knowledge Management, Oxford, England. Retrieved from http://eprints.kingston.ac.uk/2291/ (02 Jun. 2014).

Gourlay, S. (2006). Conceptualizing Knowledge Creation: a Critique of Nonaka's Theory. Journal of Management Studies, 43(7), p. 1415-1436.

Hallet, M., Mota, M., Pinot, J.H., Smack, M., Soegaard, P. (2009). Introduction to the NATO Lessons Learned Capability. The Three Swords Magazine, 16, 38-45. Retrieved from http://www.jwc.nato.int/media/three-swordsmagazine/118-issue-no-16 (28 Feb. 2014).

Hutson, P. (2011). Information and Knowledge Management: Framing the Challenge. The Three Swords Magazine, 19, 46-49. Retrieved from http:// www.jwc.nato.int/media/three-swords-magazine/121-issue-no-19 (28 Feb. 2014).

Jabłoński, J., Lis, A. (2012). Lessons Learned System as a Tool of Managing Organizational Knowledge: The Case of Military Organizations. In: A. Nalepka, A. Ujwary-Gil (Eds.), Business and Non-profit Organizations Facing Increased Competition and Growing Customers' Demands (pp. 163-186). Nowy Sącz: Wyższa Szkoła Biznesu - National Louis University. Jashapara, A. (2004). Knowledge Management: An Integrated Approach. Harlow: Prentice Hall.

JP 3-0 (2011). Joint Operations. Retrieved from http://www.dtic.mil/doctrine/ new_pubs/jp3_0.pdf (02 Jun. 2014).

JP 3-07 (1995). Joint Doctrine for Military Operations Other Than War. Retrieved from http://www.bits.de/NRANEU/others/jp-doctrine/ jp3_07.pdf (02 Jun. 2014).

Lackey, S.W. (2003). Spreading the Gospel of Lessons Learned: From the PfP Lessons Learned Working Group to Advanced Distributed Learning. Connections: The Quarterly Journal, 2, 79-90. Retrieved from http:// connections-qj.org/node/2463 (29 Mar. 2014).

Lis, A. (2012a). Positive Organizational Behaviors as the Key Success Factors for Lessons Learned Systems: The Case of Military Organizations. Journal of Positive Management, 3 (1), 82-93. Retrieved from http://www.jpm. umk.pl/images/Vol3_No1/article24.pdf (29 Mar. 2014).

Lis, A. (2012b). How to Strengthen Positive Organizational Behaviors Fostering Experiential Learning: The Case of Military Organizations. Journal of Entrepreneurship, Management and Innovation, 8 (4), 21-34. Retrieved from http://jemi.edu.pl/uploadedFiles/file/JEMI_2012_Vol_8_Articles/ JEMI_2012_Vol_8_Issue_4_Article_2.pdf (29 Mar. 2014).

Mains, S., Ariely, G.A. (2011). Learning While Fighting: Operational Knowledge Management That Makes a Difference. PRISM, 2(3), 165-176. 
Retrieved from http://www.isn.ethz.ch/Digital-Library/Publications/ Detail/?lng=en\&id=133826 (25 Mar. 2014).

McIntyre, S.G., Gauvin, M., Waruszynski, B. (2003), Knowledge Management in the Military Context. Canadian Military Journal, Spring 4(1), 35-40. Retrieved from http://www.revue.forces.ca/vo4/no1/doc/v4n1-p35-40eng.pdf (24 Mar 2014).

Milton, N. (2010). The Lessons Learned Handbook: Practical Approaches to Learning from Experience. Oxford: Chandos Publishing.

NATO E-learning Concept (2014). Retrieved from http://www.act.nato.int/ images/stories/structure/jft/NATO_e-Learning_Concept_Jan_2014.pdf (28 Feb. 2014).

Nonaka, I. (1991). The Knowledge-Creating Company. Harvard Business Review, November-December, 96-104.

Nonaka, I. (2012), Dynamic Organizational Capabilities: Distributed Leadership and Fractal Organization. In: Strategic Management of Military Capabilities: Seeking Ways to Foster Military Innovation. NIDS International Symposium on Security Affairs. Tokyo: The National Institute for Defense Studies. Retrieved from http://www.nids.go.jp/ english/event/symposium/pdf/2012/E-01.pdf (28 Feb. 2014).

Nonaka, I., Konno, N. (1998). The Concept of 'Ba': Building a Foundation for Knowledge Creation. California Management Review, 40(3), 40-54.

Nonaka, I., Takeuchi, H. (1995). The Knowledge Creating Company. New York: Oxford University Press.

Powell, T.H. (2007). a Critical Review of Nonaka's SECI Framework. Paper presented at Advanced Doctoral Seminar, 16th EDAMBA Summer Academy, Soreze, France. Retrieved from http://www.academia. edu/714629/A_Critical_Review_of_Nonakas_SECl_Framework (02 Jun 2014).

The NATO Lessons Learned Handbook (2011). Monsanto: Joint Analysis and Lessons Learned Centre. Retrieved from http://www.jallc.nato.int/ newsmedia/docs/Lessons_Learned_Handbook_2nd_edition.pdf Feb. 2014).

Wenger, E.C., McDermott, R., Snyder, W.M. (2002). Cultivating Communities of Practice: a Guide to Managing Knowledge. Boston: Harvard Business School Press.

Wheatley, M.J. (1994). Can the U.S. Army Become a Learning Organization? The Journal of Quality and Participation, 17(2), 50-56.

\section{Abstrakt (in Polish)}

Celem artykułu jest analiza procesów tworzenia $i$ konwersji wiedzy $w$ organizacjach wojskowych. Do analizy zastosowano model SECI wykorzystywany w organizacjach biznesowych. W artykule, po pierwsze, dokonano identyfikacji i kategoryzacji działań ukierunkowanych na tworzenie wiedzy organizacyjnej w środowisku wojskowym. Następnie szczegółowej analizie poddano wybrane techniki i narzędzia wykorzysty- 
wane do socjalizacji, eksternalizacji, kombinacji i internalizacji wiedzy w NATO i Armii Stanów Zjednoczonych. Omówiono zastosowanie counsellingu, coachingu i mentoringu do pobudzania i wspierania procesów socjalizacji wiedzy. Wskazano na rosnqca rolę odgrywanq w środowisku wojskowym przez wspólnoty praktyków. Przedstawiono rozwiqzania wspierajqce eksternalizację wiedzy takie jak systemy wykorzystania doświadczeń (Lesssons Learned) i procedura After Action Review. Poddano analizie standaryzację operacyjnq jako przykład procesu kombinacji wiedzy ukierunkowanego na kodyfikację dostępnej wiedzy w formie doktryn i wojskowych dokumentów normatywnych. Wreszcie skoncentrowano uwagę na szkoleniu i kształceniu w organizacjach wojskowych, które to procesy majq służyć internalizacji wiedzy przez członków organizacji.

Słowa kluczowe: model SECl, organizacje wojskowe, socjalizacja wiedzy, eksternalizacja wiedzy, kombinacja wiedzy, internalizacja wiedzy, counseling, coaching, mentoring, wspólnoty praktyków, systemy wykorzystania doświadczeń, after action review, standaryzacja operacyjna, szkolenie i kształcenie wojskowe, ćwiczenia wojskowe.

\section{Biography}

Andrzej Lis, Ph.D. is an Assistant Professor at the Faculty of Economic Sciences and Management, Nicolaus Copernicus University, Toruń and a staff officer of the Doctrine and Training Centre of the Polish Armed Forces, Bydgoszcz. His area of research activity encompasses the issues of knowledge management, change management, defence industry and military logistics, while the main research interest is focused on Lessons Learned processes. He is an experienced trainer of Lessons Learned in the armed forces. The Faculty of Economic Sciences and Management, Nicolaus Copernicus University, ul. Jurija Gagarina 11, 87-100 Toruń, Poland, Doctrine and Training Centre of the Polish Armed Forces, Bydgoszcz, Poland. Email: andrzejlis@econ.umk.pl. 